\title{
Record of Early Toarcian carbon cycle perturbations in a nearshore environment: the Bascharage section (easternmost Paris Basin)
}

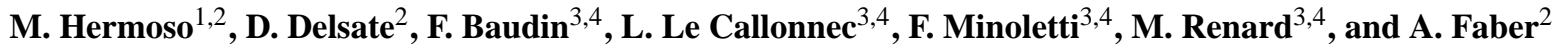 \\ ${ }^{1}$ University of Oxford - Department of Earth Sciences, South Parks Road, Oxford OX1 3AN, UK \\ ${ }^{2}$ Musée National d'Histoire Naturelle - Centre de Recherche Scientifique, 25 Rue Münster, 2160 Luxembourg, Luxembourg \\ ${ }^{3}$ UPMC Université Paris 06 - UMR7193 ISTeP, 4 Place Jussieu, 75005 Paris, France \\ ${ }^{4}$ CNRS - UMR7193 ISTeP, 4 Place Jussieu, 75005 Paris, France
}

Correspondence to: M. Hermoso (michael.hermoso@earth.ox.ac.uk)

Received: 27 March 2014 - Published in Solid Earth Discuss.: 16 April 2014

Revised: 15 June 2014 - Accepted: 17 June 2014 - Published: 6 August 2014

\begin{abstract}
In order to understand the significance of the worldwide deposition of black shale facies in the Early Toarcian $(\sim 183 \mathrm{Ma})$, considerable attention has been drawn to this Early Jurassic sub-stage over the last 3 decades. The discovery of a pronounced negative carbon isotope excursion (CIE) within the black shales disrupting the generally positive trend in carbon isotopes has stimulated many studies, particularly with a view to establish the local versus global nature of this major geochemical phenomenon. Here we document the sedimentological and chemostratigraphic evolution of a proximal environment in the Luxembourgian sedimentary area. At Bascharage, Lower Toarcian sediments record the isotopic signature of the Early Toarcian oceanic anoxic event (OAE) by a pronounced positive trend that testifies for widespread anoxia. The expression of the carbon isotope perturbation in this section, however, is unusual compared to adjacent NW European sections. A first $-7 \%$ negative CIE, whose onset is recorded at the top of the tenuicostatum zone, can be assigned to the well-documented and potentially global Toarcian carbon isotope excursion (T-CIE) with confidence using the well-constrained ammonite biostratigraphic framework for this section. In this interval, facies contain only a limited amount of carbonate as a result of intense detrital supply in such a proximal and shallow environment. Stratigraphically higher in the section, the serpentinum zone records a subsequent CIE $(-6 \%$ ) expressed as four negative steps, each being accompanied by positive shifts in the oxygen isotopic composition of carbonate. The preservation state of coccoliths and calcareous dinoflagellates in the second CIE is excellent and comparable to that observed
\end{abstract}

in under- and overlying strata, so this cannot be an artefact of diagenesis. Considering the nature of this record, and the lack of such a pronounced event in the serpentinum zone in coeval sections in Europe, we hypothesise that this second CIE was caused by local factors. The geochemical record of carbonate with a relatively light carbon and relatively heavy oxygen isotopic composition is compatible with the so-called Küspert model, by which a CIE can be explained by an influx of ${ }^{12} \mathrm{C}$-rich and cold waters due to upwelling bottom water masses.

\section{Introduction}

Despite multiple studies that have attempted characterisation of the evolution in palaeoenvironment coeval with the accumulation of black shales in the Early Toarcian, we still need to gain a mechanistic understanding of the combination of biological and oceanographic processes that drove seawater into an anoxic/euxinic state. The whole Early Jurassic epoch recorded evidence for oxygen restriction in the European epicontinental seaways, but some intervals corresponded to more severe episodes of oxygen depletion, as during the Early Toarcian oceanic anoxic event - commonly referred to as the T-OAE (Jenkyns, 1988). As most of the documented sections hitherto originate from the former $\mathrm{Eu}-$ ropean epicontinental seaways, it is essential to untangle the influence of local settings (shallow water depth, short distance from the coast, restricted marine circulation) to infer a global picture of Early Toarcian environmental changes. 
Hence, there is still a need to document the evolution of seawater physico-chemistry for a wide range of sections in $\mathrm{Eu}-$ rope, yet corresponding to contrasting depositional environments.

Even within the European area, which only represented a minor portion of the global oceanic surface, two realms are recognised based on the analysis of sedimentological and geochemical data, each of them being characterised by contrasted records of the T-OAE. The NW European platform corresponded to very shallow marine environments (100 to $200 \mathrm{~m}$ in water depth; Röhl et al., 2001) with substantial (>10\%) organic carbon content (Baudin et al., 1990). The most studied sedimentary basins representing this environment comprise the Cleveland Basin (Yorkshire), the Paris Basin (France), and the SW German Basin (Küspert, 1982; Sælen et al., 2000; Röhl et al., 2001; Bailey et al., 2003; Kemp et al., 2005; Hermoso et al., 2009). By contrast, the Mediterranean realm was more open to the western Tethys and experienced a lower degree of anoxia with relatively modest black shale deposition both for their stratigraphic extension and their organic content, typically ranging from 1 to $3 \%$ (Jenkyns and Clayton, 1986; Baudin et al., 1990; Parisi et al., 1996; Hermoso et al., 2009; Sabatino et al., 2009). The isolation of NW European and Mediterranean water masses is further supported by distinct ammonite fauna for the entire duration of the Early Toarcian (Elmi et al., 1994, 1997; Macchioni, 2002). Taxa became subsequently homogenised in the middle Toarcian owing to the second-order Liassic transgression and the flooding of the NW European realm (Hardenbol et al., 1998). In addition, the expression of the T-OAE and the depositional environments were yet very different within each of these realms. This feature is explained by active regional tectonic that separated many intracratonic subbasins by shoals, tectonically corresponding to horsts (Gély and Lorenz, 1996).

The intracontinental Paris Basin was formed by sediment accumulation comprised between the main emergent lands inherited from the Hercynian orogenesis: the Central Massif (south), the Armorican Massif (west), the London-Brabant Massif (north), and the Rhenish Basin (east) (Fig. 1a). The basin remained connected eastwards to the SW German Basin, as evidenced by common Boreal ammonite fauna. At the farthest eastern reaches of the Paris Basin, Lower Jurassic sedimentary formations are exposed in the south of Luxembourg and correspond to expanded intervals compared to adjacent sections in NE France (Lucius, 1948; Hanzo and Espitalié, 1993) (Fig. 1b). This region corresponded to proximal environments with substantial detrital influence from the Ardennes at sites of deposition. Abundant body fossils of reptiles, fish, crustaceans, insects and higher plants confirm the nearshore nature of this region (Delsate et al., 1995, 1999; Henrotay et al., 1998; Nel et al., 2004; Dera et al., 2009).

In the present study, we characterised palaeoenvironmental changes through the Pliensbachian-Toarcian transition and the T-OAE as recorded in the Bascharage section ex- posed in the SW of Luxembourg. In such proximal setting, the record is most prone to be affected by local factors such as change in sea level, riverine run-off, coastal circulation, and temperature, and therefore potentially bears maximum modulation of the expression of the global T-OAE. Examining the dynamics of the carbon cycle, in particular with regard to the well-documented prominent negative carbon isotope excursion that is recorded within the T-OAE (Hesselbo et al., 2000), may hence provide valuable information on the impact of local factors on the record of Late PliensbachianEarly Toarcian climate and the carbon cycle.

\section{The Bascharage composite section}

\subsection{Regional settings}

Rocks exposed in the south-west of the Grand Duchy of Luxembourg correspond to Lower Jurassic (Liassic) sedimentary formations (Fig. 1a). Bascharage is a city in the vicinity of the French-Belgian border (Fig. 1b). The composite section presented in this study is composed of two intervals distant of about $500 \mathrm{~m}$. The first interval ( $3.6 \mathrm{~m}$ thick) was exposed in the industrial zone "Op Zämer" (Fig. 2). The second interval $(7.2 \mathrm{~m})$ is situated along the Prince Henri railway connecting Pétange to Luxembourg City, at the west of the industrial zone "Bommelscheuer". We can estimate a maximum nonobservational hiatus of less than 50 centimetres between the two sections thanks to topographic data provided by the Luxembourgian railway company. This composite interval spans the Late Pliensbachian and the Early Toarcian sub-stages. The last metre of the Bommelscheuer outcrop consists of highly altered facies due to the activity of the vegetal cover overlaying the section.

\subsection{Sedimentology, lithostratigraphy and biostratigraphy}

The Op Zämer section exhibits Upper Pliensbachian strata corresponding to the Marnes d'Ottemt Formation (Fig. 2). Facies consist of pale grey clayed sediments with an abundant macrofauna (belemnites, brachiopods, bivalves and ostracods). Another prominent feature of this sedimentary unit, dated in the spinatum zone, is the considerable number of centimetric limonite nodules (from the base up to $80 \mathrm{~cm}$ in this section) and subsequent phosphate (apatite) nodules from 80 to $120 \mathrm{~cm}$. The sedimentary unit overlaying the Pliensbachian-Toarcian boundary consists of clayed orange facies in which no ammonite specimens were observed. This level corresponds to the lower part of the Marnes à Semicelatum Formation, biostratigraphically assigned to the tenuicostatum zone in SE Belgium (Delsate, 1990; Boulvain et al., 2001). The following unit consists of dark blue/grey calcareous claystone, typical of the Marnes à Semicelatum Formation with many belemnites and large carbonate nodules whose diameters comprise between 10 and $30 \mathrm{~cm}$. This 

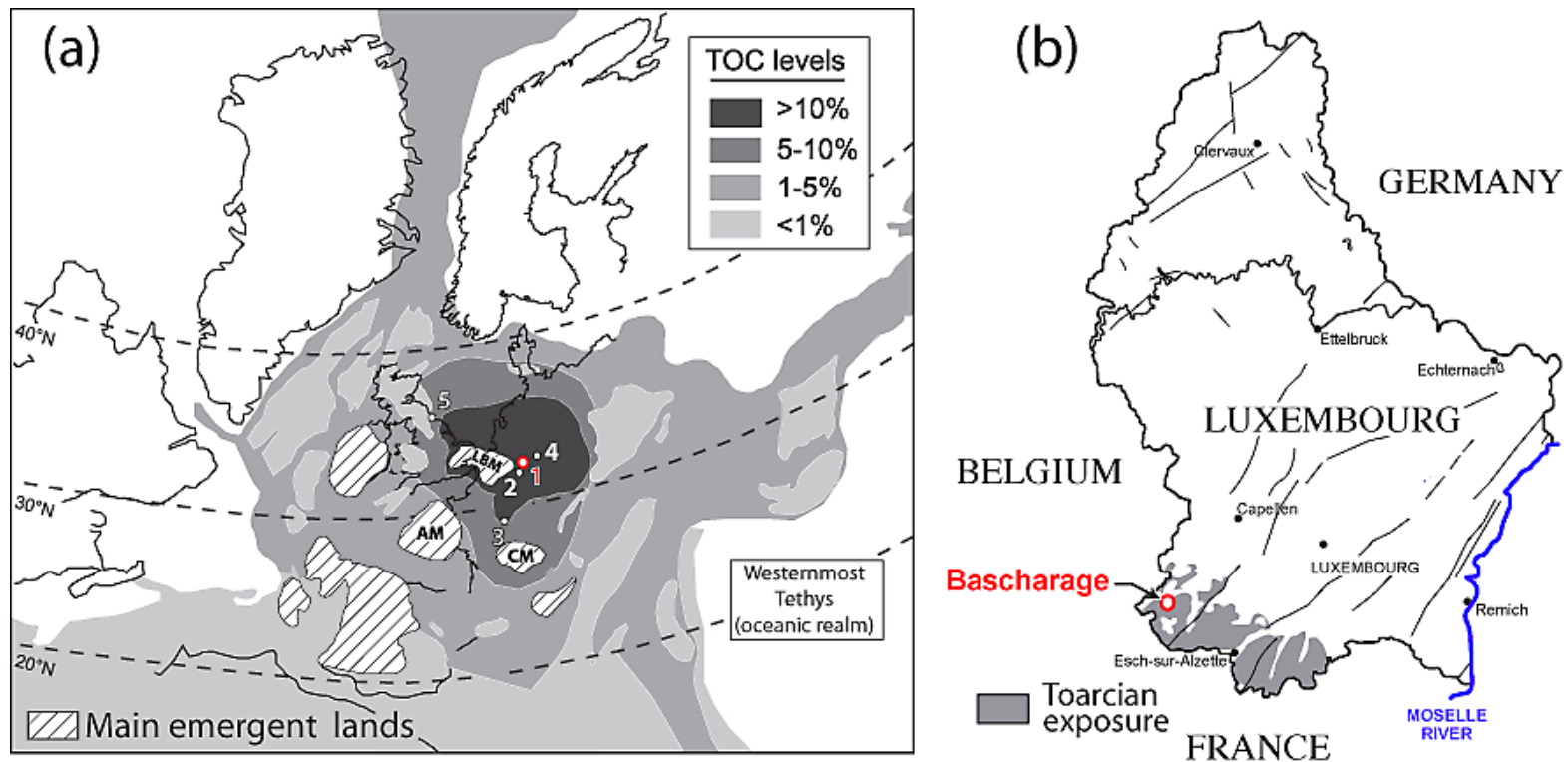

Figure 1. (a) Palaeogeographic reconstruction of the Early Jurassic epicontinental seaway, and geographic distribution of organic-rich rocks. Greyscale shades reflect average contents of total organic carbon (TOC); key is inset upper right. Emergent lands delineating the Paris Basin are hatched. CM - Central Massif, AM - Armorican Massif and LBM - London-Brabant Massif (also comprising the Rhenish Massif in its oriental portion). The map indicates the location of the Bascharage section (1), ANDRA EST433 borehole (2), Sancerre borehole (3), Dotternhausen (4) and Yorkshire coast (5). Source: Bassoulet et al. (1993), Baudin et al. (1990), Van de Schootbrugge et al. (2005), Hermoso et al. (2009). (b) Location of the Bascharage section in NW Luxembourg. The grey area represents exposures of Toarcian deposits. Map from Service Géologique (1998).

$80 \mathrm{~cm}$ thick interval is assigned to the semicelatum sub-zone of the Early Toarcian. The top of the Op Zämer section exhibits the Lower Toarcian black shales of the Schistes carton Formation (lithostratigraphically equivalent to the Jet Rock Formation in Yorkshire, or to the Posidonienschiefer Formation in SW Germany) that provide compelling evidence for supra-regional anoxia. Black shales consist of very dark and finely laminated sediments, with very scarce macropalaeontological content (restricted to few ammonite specimens and Bositra spp. casts). The contact between the Schistes carton lithology and the underlying pale grey marls is sharp and underpinned by many pluricentimetric wood fragments recovered in the Op Zämer section (Fig. 2). In adjacent regions in Belgium, a thin sandy bed containing an abundant fish macrofauna has been reported at this transition (Delsate et al., 1999).

The Bommelscheuer section spans the Early Toarcian serpentinum zone. The exposed black shales correspond to a monotonous lithological unit with, however, a notable level of nodular limestone between 5.3 and $5.5 \mathrm{~m}$ in this section (sometimes referred as to the pains pétrifiés in regional literature; cf. Hanzo, 1979), and a $30 \mathrm{~cm}$ thick limestone bed at $7.5 \mathrm{~m}$ in the composite section. This carbonate level marks the transition between the elegantulum and the falciferum sub-zones. The total thickness of the Schistes carton Formation in this sedimentary area is of the order of $60 \mathrm{~m}$ (Hanzo and Espitalié, 1993). The overlying Marnes à Bifrons Forma- tion of the middle Toarcian (not exposed at Bascharage) still records evidence of anoxia with sediment lamination (Delsate, 1990; Hanzo and Espitalié, 1993; Boulvain et al., 2001; Dera et al., 2009).

\section{Methods}

The carbonate content of the sediments were measured at Oxford University using a Stroehlein Coulomat 702 apparatus. To remove to organic carbon, crushed samples were roasted overnight at $420^{\circ} \mathrm{C}$ and subsequently combusted from 800 to $1200^{\circ} \mathrm{C}$ under an oxygen flush. Measured $\mathrm{CO}_{2} / \mathrm{CO}$ were quantified by coulometric determination and translated into \% weight carbonate by multiplying the carbon content by a factor of 8.3 (the elemental $\mathrm{CaCO}_{3} / \mathrm{C}$ ratio). Reproducibility of measurements, based on replicate analyses of an in-house standard, was usually better than $0.5 \%$.

Total organic carbon (TOC) content and Rock-Eval parameters of the organic matter were measured at UPMC Paris using a Rock-Eval II apparatus. Temperature in the pyrolysis programme at which a maximum of hydrocarbon was released is termed $T_{\max }$ and provides information on the thermal maturity of the organic matter. The hydrogen index (HI), expressed as milligrams of hydrocarbon per gram of organic carbon, is used to determine the origin of the organic matter, with terrestrial (continental) organic matter being more 
$(\mathrm{cm})$

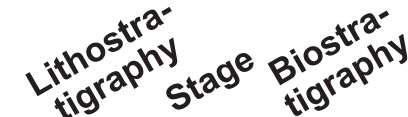

Main lithology Ammonites Main features

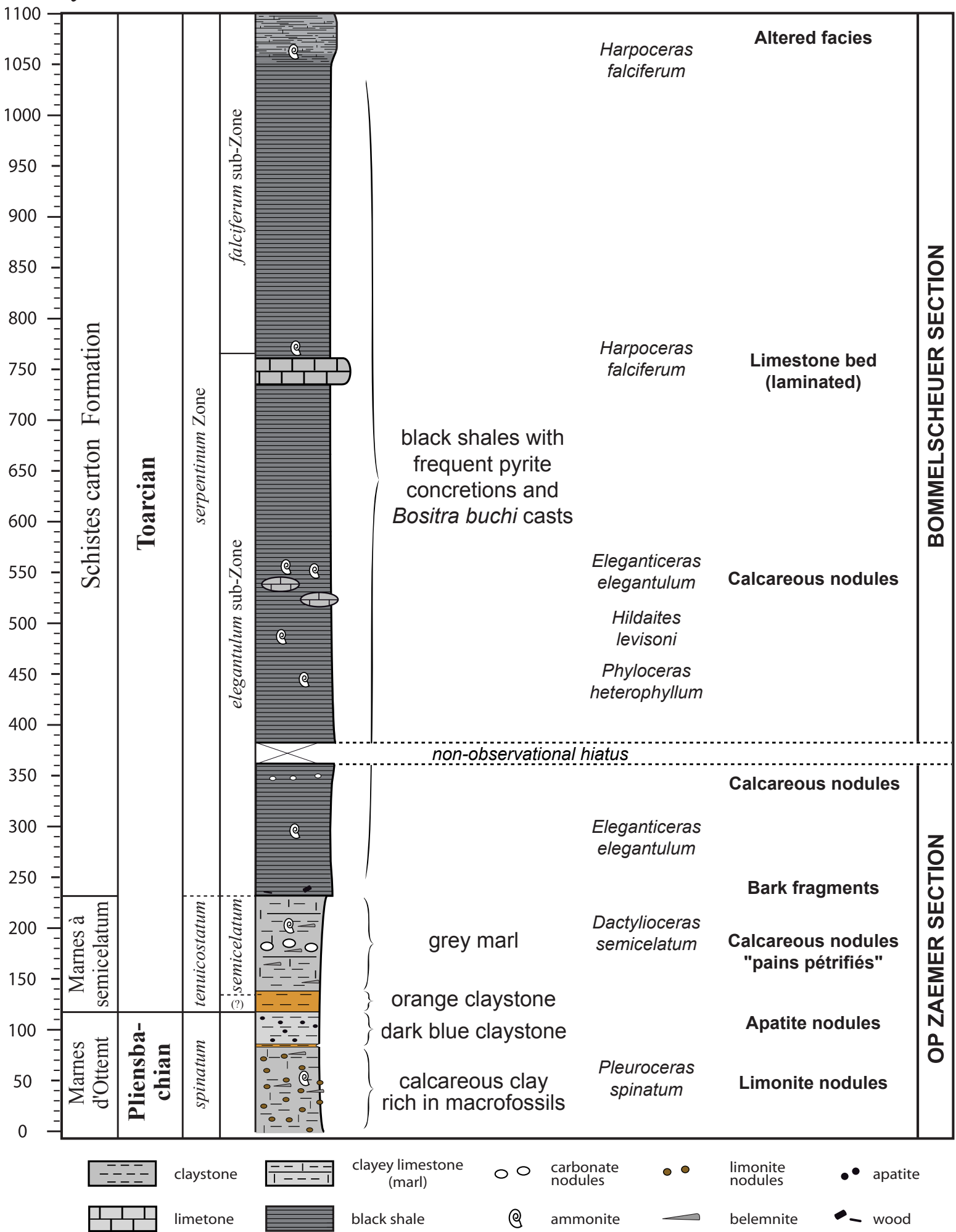

Figure 2. Lithostratigraphy, biostratigraphy and main lithological description of the composite section of Bascharage spanning the Late Pliensbachian to Early Toarcian intervals of the Op Zämer and Bommelscheuer outcrops. 
hydrogen-depleted with respect to oxygen than phytoplanktonic organic matter. The typology of organic matter by Tissot et al. (1971) includes a Type III with relatively low ( $<100 \mathrm{mg}$ of hydrocarbon per gram of TOC) HI characteristic of continental organic matter, and a Type II with higher HI (of the order of 600) that indicate marine phytoplanktonic origin.

Samples were measured for their carbon and oxygen isotopes at Oxford University using a VG Isogas Prism II mass spectrometer with an online VG Isocarb. An approximate mass of $50 \mathrm{mg}$ of sample was finely crushed, and $10 \mathrm{mg}$ was reacted with anhydrous phosphoric acid at $90^{\circ} \mathrm{C}$. Calibration to V-PDB standard is made using the NOCZ internal standard. Reproducibility of the analyses is better than $0.1 \%$ for carbon and oxygen isotopes.

Initial attempts to measure the isotopic composition of the organic matter produced poor quality and unrealistic data that have been discarded. Unfortunately, subsequent $\delta^{13} \mathrm{C}$ analyses of these samples were not possible.

$\mathrm{X}$-ray diffraction of samples distributed along the Schistes carton Formation revealed that the carbonate mineralogy is calcium carbonate (Hermoso, 2007). The nature and preservation of calcitic particles in the sediments were examined using both optical and electronic microscopes. Smear slides were observed under a cross-polarised Zeiss microscope fitted with a $63 \times$ objective enabling high-magnification observation (Minoletti et al., 2009). Some selected samples were investigated with a scanning electron microscope (SEM) to assess the preservation of calcareous nannofossils, which, where present (Schistes carton Formation), was always very good (Fig. 3). Importantly for the interpretation of isotopic signals, no recrystallisation feature or overgrowth on coccoliths were observed throughout the black shale interval.

\section{Results}

\subsection{Carbonate content and total organic carbon}

In the Pliensbachian, deposits are characterised by low to extremely low carbonate content (Fig. 4). The first lithological unit $(0-0.7 \mathrm{~m})$ contains about $15 \%$ of carbonate. The two subsequent units $(0.7-1.3 \mathrm{~m})$ are barren of carbonate phase. The grey marls between 1.3 and $2.3 \mathrm{~m}$ are relatively rich in calcite up to the nodular level at $1.8 \mathrm{~m}$, and subsequently becomes carbonate-depleted at the top of this unit. With the emplacement of black shales, the carbonate content shows a transient enrichment with content up to $30 \%$. No carbonate was detected in the black shales between 2.6 and $3.4 \mathrm{~m}$. This observation could be related to weathering of the top of the Op Zämer section although facies did not appear to be macroscopically altered. Above the level distinguishable by the presence of small calcareous concretions at $3.5 \mathrm{~m}$, the carbonate fraction of the sediment progressively increases up to the limestone bed at $7.5 \mathrm{~m}$. This increase is considerable

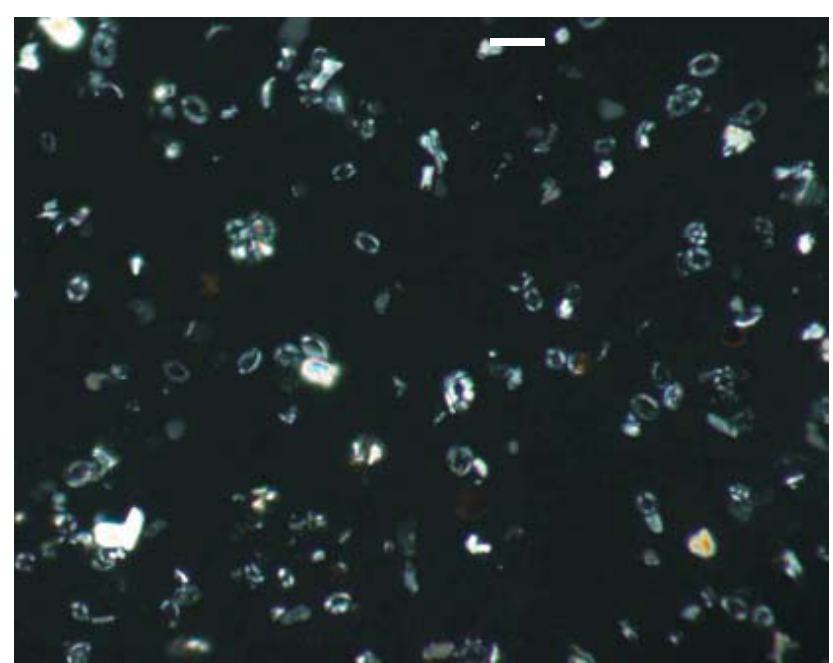

Figure 3. Cross-polarised microphotograph of Lower Toarcian black shales exposed at Bascharage - sample from the Schistes carton Formation at $6 \mathrm{~m}$ in this section. This image illustrates the good preservation state of coccoliths and the reduced abundance of diagenetic particles (scale bar: $10 \mu \mathrm{m}$ ). Microseparated assemblage taken from Minoletti et al. (2009).

by its magnitude with carbonate contents changing from $\sim 0$ to $60 \%$. This mineralogical change mostly corresponds to enrichment in calcareous nannofossils in the sediments. It has to be noted that even if the lithological expression of this limestone level is clear with respect to the hosting black shale facies, the increase in carbonate is also elevated in both under- and overlaying sediments. The same remark applies for the interval containing the nodules at about $5.3 \mathrm{~m}$ in this section. The top of the section shows a decline in the carbonate content, although the content remains relatively high, about $30 \%$.

The TOC content is negligible in the Upper Pliensbachian and lowermost Toarcian deposits before the onset of black shales (Fig. 4). The organic content in the black shales gradually increases, reaching a maximum of $\sim 22 \%$ at $3.5 \mathrm{~m}$ in this section. Subsequently, the TOC shows a rapid diminution up to the nodular level at $5.5 \mathrm{~m}$. The organic content of rocks remains at relative high levels of $10 \%$ in the elegantulum sub-zone. In the falciferum sub-zone, minimum contents of $5 \%$ are observed.

\subsection{Carbon and oxygen isotope from bulk carbonate samples}

Overall, carbon isotopic ratios measured from bulk carbonate rocks are comprised in a substantially wide array $( \pm 10 \%$ o (Fig. 4). During the Pliensbachian, the ratios are stable and about $0 \%$ in sediments with more than $10 \%$ carbonate, corresponding to grey calcareous marls ( 0 to 0.7 and 1.4 to $2 \mathrm{~m}$ ). The $\delta^{13} \mathrm{C}$ values are strikingly very negative when the carbonate content is low $(<10 \%)$, raising question about the 


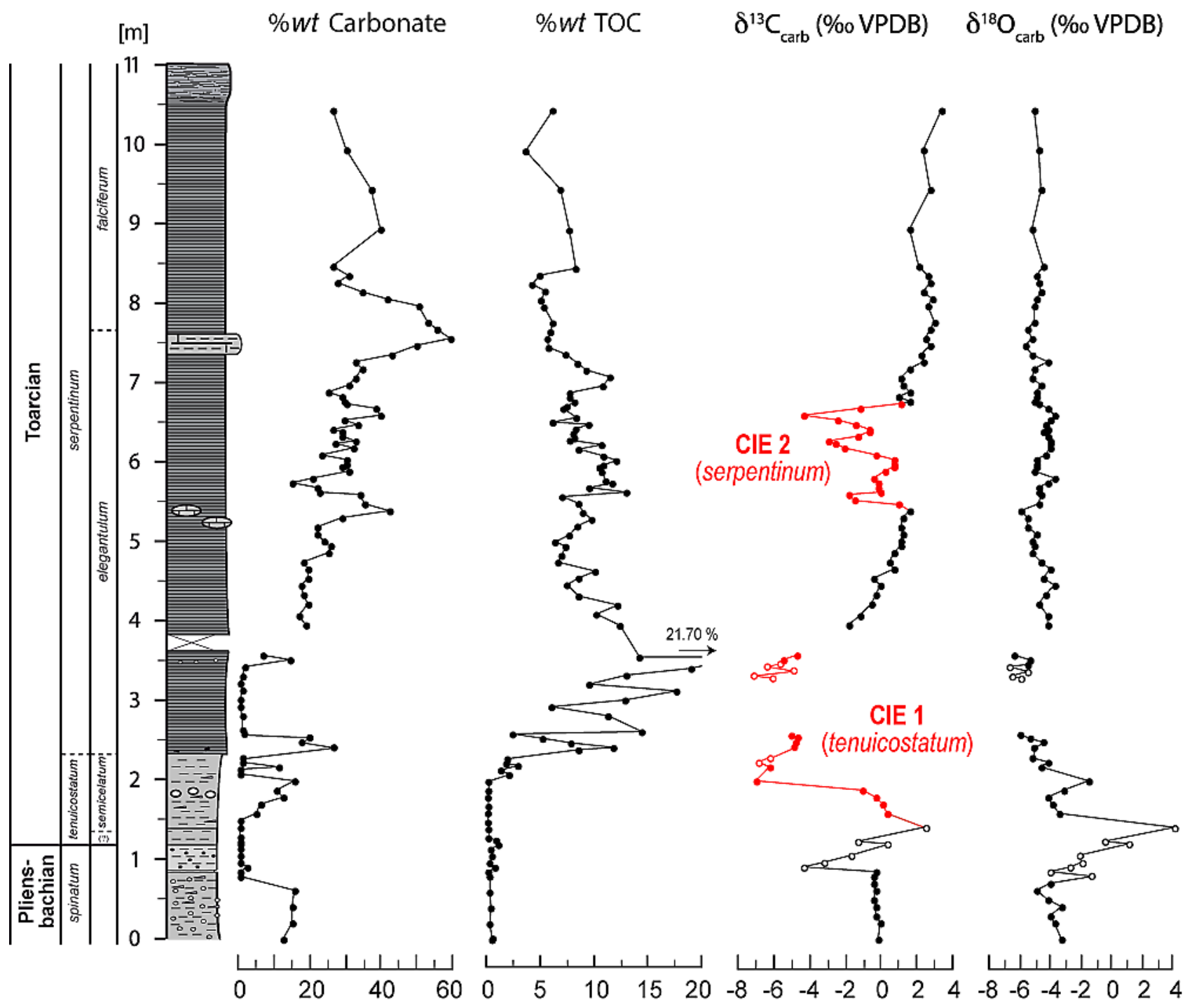

Figure 4. Evolution in carbonate $\left(\% \mathrm{CaCO}_{3}\right)$ and total organic carbon (\% TOC) content, and stable isotopes (carbon and oxygen) from carbonate for the Bascharage section. Open circles indicate samples with very low (typically <10\%) carbonate content, challenging the validity or meaning of stable isotopes data in such clay facies. During the Early Toarcian, the oceanic anoxic event is expressed by the overarching positive trend in carbon isotope ratios, accompanied by an increase in the carbonate (coccolith) content in Bascharage. Red portions of the curves represent the CIEs: a first one (CIE 1) with a magnitude of $-6 \%$ in the tenuicostatum zone, which can be stratigraphically assigned to the widely documented T-CIE. A subsequent $-6 \%$ and stepped CIE (CIE 2) in the serpentinum zone is expressed in well-preserved coccolith-bearing sediments. Coeval oxygen isotope shows heavier signatures during each of the fourth step of the CIE 2 (see Fig. 6).

validity of such measurements. It is otherwise significantly lower, comprising between -4 and $-6 \%$ in carbonatedepleted intervals. In the tenuicostatum zone, the top of the Marnes à Semicelatum and the base of the black shales characterised by relatively high carbonate content shows $\delta^{13} \mathrm{C}$ values at around $-7 \%$ and $-5 \%$, respectively. Due to the lack of carbonate in the 2.6 to $3.4 \mathrm{~m}$ interval, no isotopic ratios were successfully measured. With the carbonate content increase from $3.4 \mathrm{~m}, \delta^{13} \mathrm{C}$ values are slightly more negative, about $-6 \%$ (Fig. 4). This "jump" in $\delta^{13} \mathrm{C}$ values represents a carbon isotope excursion (CIE) of $\sim-7 \%$ (CIE 1 there- inafter); although, the descending limb of this excursion is not well defined. After the non-observational hiatus corresponding to the transition between the Op Zämer to the Bommelscheuer sections, a clear post-CIE 1 increase in $\delta^{13} \mathrm{C}$ is observed with ratios reaching $\sim+2 \%$ at $5.4 \mathrm{~m}$. Between 5.4 and $6.8 \mathrm{~m}$ (serpentinum zone), a stepped negative CIE (CIE 2) with a total magnitude of $\sim-6 \%$ is observed, whilst carbonate contents remain relatively high and even show a slight increase throughout this second CIE (disregarding the enriched level containing the calcareous nodules). Above the CIE 2, the $\delta^{13} \mathrm{C}$ increase is resumed and maximum isotopic 
ratios of $\sim+3.5 \%$ are reached at the base of the falciferum sub-zone (Figs. 4 and 5). Such high $\delta^{13} \mathrm{C}$ ratios persist up section irrespective of the appreciable fluctuations in the carbonate content.

By contrast to the carbon isotopes, oxygen isotopic ratios measured in intervals with very low carbonate content show more positive values. The base of the section records $\delta^{18} \mathrm{O}$ values around an average of $-4 \%$. The uppermost Pliensbachian and lowermost Toarcian sediments present an offset of $+8 \%$. In the Lower Toarcian interval, including the base of the black shales, the ratios are in the range of -4 and $-6 \%$. Such negative $\delta^{18} \mathrm{O}$ ratios persist throughout the whole black shales at Bascharage. In detail, although the variations are not as intense as for $\delta^{13} \mathrm{C}$, the evolution in the oxygen isotope ratios mirror those of the carbon isotopes (Figs. 4 and 6). This is especially the case for the significant $\delta^{13} \mathrm{C}$ increase between 3.4 and $5.4 \mathrm{~m}$, and throughout the CIE 2 in the serpentinum zone during which each negative step is seen with a +0.75 to $+1 \%$ increase in $\delta^{18} \mathrm{O}$ (Fig. 6).

\subsection{Rock-Eval parameters}

We used the Rock-Eval characterisation of the organic matter only for TOC content above $\sim 1 \%$ (Figs. 4 and 5). Below the black shale facies (i.e. in the Marnes à Semicelatum Formation), there is a clear decrease in $T_{\max }$ and increase in hydrogen indexes. Taken together, the Rock-Eval parameters indicate a shift from continental-dominated organic matter towards marine (phytoplanktonic) organic matter. Following the typology of the sedimentary organic matter by Tissot et al. (1971), this change corresponds to a progressive, but marked, transition from Type III to Type II. Stable and persistent Type II composition within black shales is recorded underneath the nodular level of the elegantulum sub-zone (at $\sim 4.8 \mathrm{~m}$ ). The decrease in $T_{\max }$ does not correspond to a change in the thermal evolution of the section, but is related to the change in both the type and preservation of organic matter. Indeed, Type III usually shows higher $T_{\max }$ than Type II for the same thermal level (Espitalié et al., 1986), and the oxidation of organic matter removes the labile fraction of the organic matter leading to the selective preservation of a more thermally resistant organic fraction.

Stratigraphically above the nodular level, a decrease in the TOC content is observed, albeit with relatively unchanged $\mathrm{HI}$ and $T_{\max }$. An interval between 7.8 and $8.4 \mathrm{~m}$, however, exhibits lower TOC and HI.

\section{Discussion}

\subsection{The Pliensbachian-Toarcian boundary}

The base of the section containing more than $10 \%$ of carbonate shows stable isotopic ratios of $0 \%$ (carbon) and $-4 \%$ o (oxygen). These absolute isotope ratios measured from carbonate at the end of the Pliensbachian are comparable to

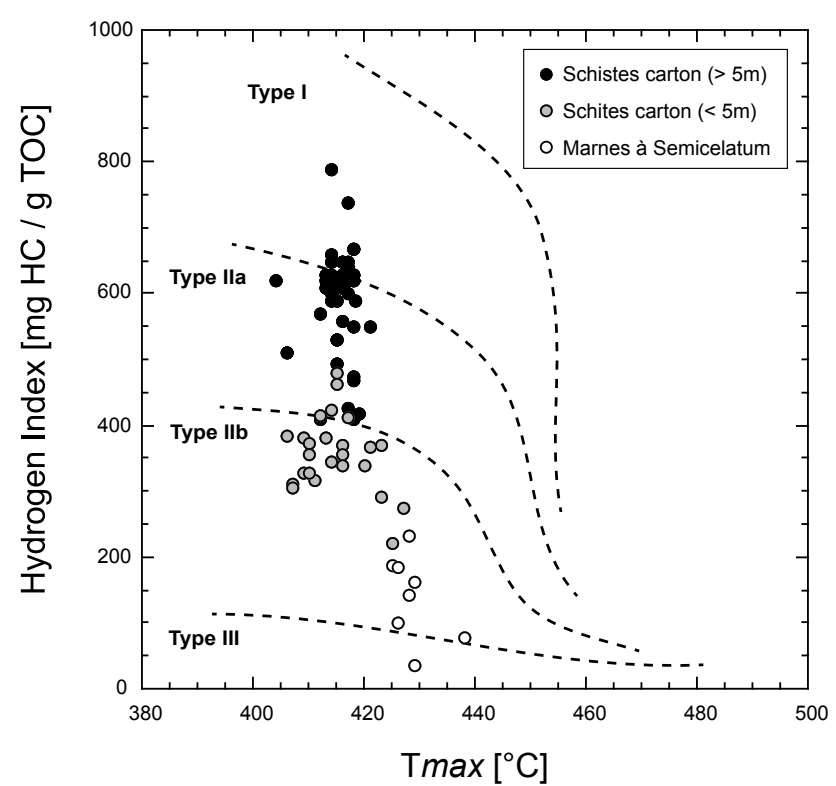

Figure 5. Pseudo van Krevelen diagram showing the origin of the organic matter of the Lower Toarcian samples of the Bascharage section. The typology of the organic matter according to combined hydrogen index and $T_{\max }$ values is after Tissot et al. (1971). Symbols correspond to the (litho)stratigraphic position of the samples across the section. Key is inset upper right. The samples show a progressive increase in HIs throughout the section, indicating a progressive change from continental (Type III)- to marine (Type II)dominated organic matter. Representation of $T_{\max } / \mathrm{HI}$, as referred to as a pseudo van Krevelen plot is from Espitalié et al. (1986).

other data from the Paris Basin (Röhl et al., 2001; Hermoso et al., 2013). This basin-scaled feature may indicate homogenous water masses in the basin, including near-identical temperature status during the end of the Pliensbachian.

Higher in the section, but still in the Pliensbachian, detrital facies and complex mineralogy (phosphate/carbonate) hamper generation of meaningful isotopic records. In nearshore environments, rapid fluctuations in the composition of seawater are related to fresh-water supply from the continent (with low $\delta^{18} \mathrm{O}$ ). The delivery of fresh water can overprint the temperature record in $\delta^{18} \mathrm{O}_{\text {carb. }}$. It has to be acknowledged that no palaeoenvironmental information can be deduced from the Bascharage record to characterise the Pliensbachian-Toarcian transitional climatic change (poor carbonate content with the absence of calcareous nannofossils, presence of phosphate nodules). From a more sedimentological perspective, it can be deduced from the orange clay, coccolith-barren interval laying on the stage boundary, a drastic reduction of the water depth. Such a red or orange level immediately after the boundary has been previously reported in France and interpreted as an emersion event (Morard et al., 2003). A prominent sedimentary hiatus is widely observed at the scale of the NE Paris Basin (Boulvain et al., 2001; Van Breugel et al., 2006; Lézin et al., 2013). This 


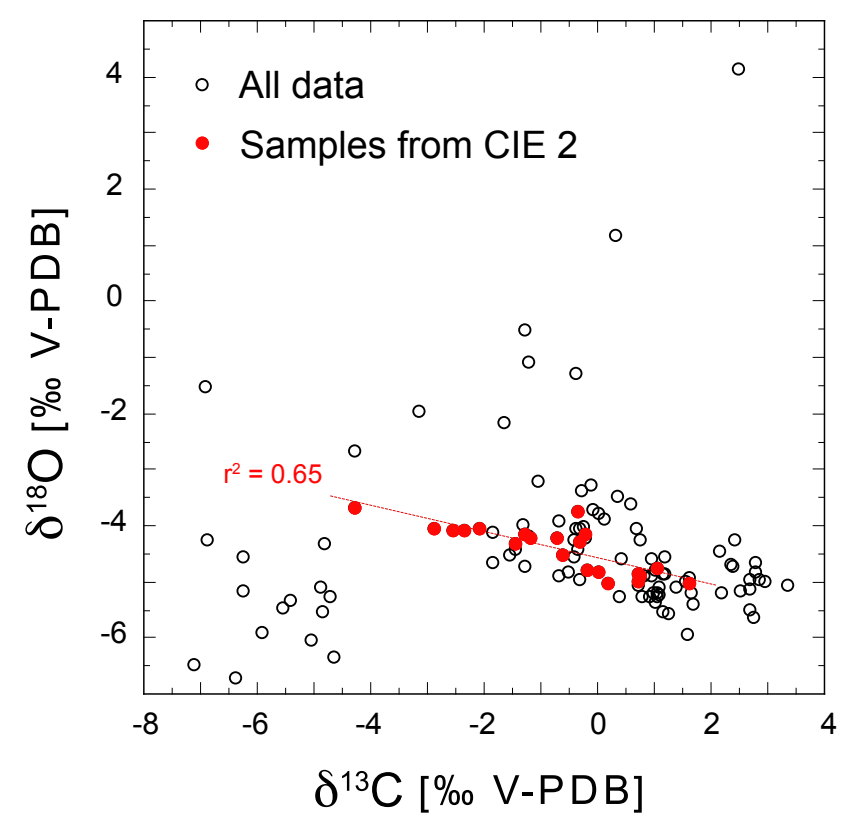

Figure 6. Scatter plot of carbon and oxygen isotopes in the Upper Pliensbachian and Lower Toarcian samples of Bascharage. Key for symbols is inset. In the serpentinum zone, coccolith-bearing samples from the CIE 2 show an anti-correlation of their isotope ratios. Each of the subsequent negative step of the carbon isotope excursion is seen with a concomitant $\sim 1.5 \%$ increase in oxygen isotopes.

stratigraphic feature explains the lack of the record of the CIE across the stage boundary between the Pliensbachian and the Toarcian, as it was reported from NE England or from the Polish Basin (Littler et al., 2010; Hesselbo and Pienkowski, 2011).

\subsection{First CIE and onset of Early Toarcian black shale (tenuicostatum zone)}

The Marnes d'Ottemt Formation corresponds to sediments that have a typical $\delta^{13} \mathrm{C}$ signature of about $0 \%$. The $\delta^{13} \mathrm{C}$ values suddenly drop, representing a $-7 \%$ o negative shift in the $\delta^{13} \mathrm{C}$ during the tenuicostatum zone (CIE 1). This large isotopic offset is compatible with the well-documented CIE. It is located within the same biostratigraphic interval, and presents a similar magnitude than in other NW European carbonate records (Hesselbo et al., 2000; Röhl et al., 2001; Kemp et al., 2005; Hermoso et al., 2009; Caruthers et al., 2011; Gröcke et al., 2011; French et al., 2014). During the CIE, reinforcement of the detrital supply has been shown elsewhere by mineralogical and geochemical data (Brański, 2012; Hermoso and Pellenard, 2014). Lower carbonate preservation can be ascribed to an episode of seawater acidification in the Paris Basin (Hermoso et al., 2012).

Throughout the top of the Marnes à Semicelatum to the Schistes carton Formations, significant increase in coccol- ith abundance and in hydrogen indices of the organic matter clearly indicates a better preservation of marine-derived organic matter and hence a greater distance of Bascharage from the coast (Fig. 5). The overall evolution in facies and carbonate content is the likely consequence of the third-order transgression during the earliest Toarcian ("Pl 8" cycle sensu Hardenbol et al., 1998). At the onset of black shales, $\delta^{13} \mathrm{C}$ values are still very low $(\sim-5 \%)$ and the measurements can be regarded as primary signals with confidence (coccoliths). The first centimetres of black shales at Bascharage are characterised by relatively high carbonate content, predominantly consisting of coccoliths (Hermoso, 2007) (Fig. 3). The hydrogen indices indicate a mixture between marine (coccolithophore) and terrestrial-derived organic matter, as confirmed by the recovery of many wood fragments. Flooding of epicontinental surfaces led to extraordinarily high primary phytoplanktonic productivity (Jenkyns, 2003; Erba, 2004), as also evidenced by a pronounced positive trend in $\delta^{13} \mathrm{C}$, and locally by the sedimentation of coccolith calcite (Figs. 4 and 5).

\subsection{A second Early Toarcian negative carbon isotope excursion (serpentinum zone)}

The broader feature associated with the T-OAE is the positive trend in the carbon isotopes that indicate burial of ${ }^{12} \mathrm{C}$ rich carbon in form of organic matter (Jenkyns et al., 2010). Local factors, such as an insufficient water depth, are not likely to affect the record of this global isotopic trend (Hermoso et al., 2013). This is well illustrated in most of Mediterranean sections in which the $\delta^{13} \mathrm{C}$ overarching positive trend is recognised without lithological expression of black shales (Hesselbo et al., 2007; Woodfine et al., 2008; Sandoval et al., 2012), ruling out a local or diagenetic control on carbon isotope signal in carbonate. Conversely, one process that is prone to substantially alter the pristine isotopic signal is diagenesis.

At Bascharage, the nature and preservation state of the carbonate particles (in majority consisting of calcareous nannofossils in the Schistes carton, Fig. 3) indicate that isotopic measurements reflect a primary signal of the photic zone (Hermoso, 2007; Minoletti et al., 2009). Low $T_{\max }$ values indicate that the studied sections did not experience strong thermal diagenesis. The record of a positive trend in $\delta^{13} \mathrm{C}$ curve provides strong evidence for a primary signal at Bascharage, provided samples contain a minimum $(\sim 10 \%)$ of carbonate. Given the reliable biostratigraphic framework established at the sub-zone level for the Bascharage section, and considering the $2 \mathrm{~m}$ thick interval that separates CIE 1 and CIE 2, we exclude that both isotopic events may correspond to different steps of the "worldwide" negative carbon isotope excursion. In the following account, we discuss the record and significance of the CIE 2 in the serpentinum zone. 


\subsubsection{Testing a diagenetic record of the CIE 2}

There are many geological intervals during which broad correlative trends between $\delta^{13} \mathrm{C}$ and $\delta^{18} \mathrm{O}$ were observed, as for the Early Toarcian (Jenkyns and Clayton, 1997; Rosales et al., 2001). The main explanation put forward to explain this observation is diagenesis (Marshall, 1992). One singularity of the Bascharage section is the observation of concomitant low $\delta^{13} \mathrm{C} /$ high $\delta^{18} \mathrm{O}$, which is a contrasting situation with other intervals thought to have experienced substantial diagenetic alteration of the primary signal (Rosales et al., 2001). An early diagenetic phase that precipitates from bottom (cold) waters would bear more positive $\delta^{18} \mathrm{O}$. Concomitantly, because the alkalinity in early diagenetic fluids derives from organic matter decay, $\delta^{13} \mathrm{C}$ is substantially shifted towards low values (Irwin et al., 1977). However, examination of nannofacies by Hermoso (2007) and Minoletti et al. (2009) in the interval comprising the CIE 2 at Bascharage does not indicate the presence of such diagenetic overprinting (Fig. 3). Carbonate assemblages and their preservation state are similar during the CIE 2 with underlying (disregarding the nodules) and overlying sediments. Both bracketing horizons record global signal, as isotopically evidenced by recognition of the long-term positive trend in $\delta^{13} \mathrm{C}$.

\subsubsection{A palaeoceanographic explanation}

The oxygen isotope ratios at Bascharage do not exhibit a negative shift concomitant to the negative CIE 2 (serpentinum zone) that would potentially indicate warming or intensification of the riverine supply at Sancerre and elsewhere (Bailey et al., 2003; Hermoso et al., 2013). This response in the $\delta^{18} \mathrm{O}$ climate-sensitive proxy represents a main difference with the expression of the CIE 1 (tenuicostatum zone). Retaining the primary record of $\delta^{18} \mathrm{O}$ at Bascharage during the CIE 2, two alternative, not necessarily exclusive, hypotheses may account for higher $\delta^{18} \mathrm{O}$ and for $\delta^{18} \mathrm{O} / \delta^{13} \mathrm{C}$ co-variation during the CIE 2 (Fig. 6). Each negative step of the descending limb of the carbon isotope excursion may have been coeval with cooling. Such cooling phase may be accompanied by diminished primary productivity, which in turn, would have led to more negative $\delta^{13} \mathrm{C}$ in carbonate. These two observations are not made at Bascharage. Furthermore, each step of the CIE 2 does not correspond to lowered concentrations in TOC. As an alternative, these discrete intervals may have been characterised by reduced input of fresh water into the basin. Both hypotheses are conflicting with our view of palaeoceanographic and palaeoclimatic event during a global event (i.e. reflecting sudden increase of atmospheric $p \mathrm{CO}_{2}$ ) regardless of its possible cause(s) as volcanism, methane hydrate release, and/or intrusion of dolerites into organic-rich formations of the Karoo region (Hesselbo et al., 2000; McElwain et al., 2005; Svensen et al., 2007; Suan et al., 2008).

The above-mentioned hypothesis relies on a top-down control of seawater chemistry whereby fluctuations of tem- perature and isotope composition are predominantly forced by a climatic (atmospheric) control. A bottom-up scenario with upwelling of cold and ${ }^{12} \mathrm{C}$-rich waters may explain the $\delta^{18} \mathrm{O} / \delta^{13} \mathrm{C}$ co-variation that characterises the record of the CIE 2 at Bascharage (Fig. 6). This explanation was originally formulated by Küspert (1982), and more recently discussed by Van de Schootbrugge et al. (2005), who claimed that the T-CIE was not a global phenomenon, but only ascribed to a local oceanographic control.

It has to be noted that a $\sim-1.5 \%$ o CIE in the falciferum zone subsequent to the "main" CIE of the tenuicostatum zone has recently been reported in the Sancerre borehole, between 328 and $324 \mathrm{~m}$ deep in the core (Hermoso and Pellenard, 2014). In the recent paper by Lézin et al. (2013), it appears also very likely that what they have interpreted as the global CIE was the CIE 2 in the serpentinum zone (Fig. 7). This possible basin-scaled correlation may indicate a regional event that affected the whole Paris Basin, albeit with a stronger magnitude in nearshore environments such as that of Bascharage.

Further investigation on this $\delta^{18} \mathrm{O} / \delta^{13} \mathrm{C}$ co-variation has to be undertaken. Notably, generating a nitrogen isotope profile through this interval would enable testing an upwelling explanation for this geochemical feature.

\section{Conclusions}

Sediments exposed at the base of the studied interval largely revealed have largely revealed to be unsuitable to apply carbonate-based isotopic proxies. Hence, palaeoenvironmental characterisation of this interval remains relatively unconstrained for this section. This feature may confirm the previously established near-emersional event around the stage boundary.

Deposition of black shales in the Early Toarcian interval overlies a transitional facies consisting of grey marls with abundant marine fauna indicating re-establishment of full marine conditions. The worldwide CIE (CIE 1) comprised in the tenuicostatum zone is recognised at Bascharage with its full amplitude compared to adjacent sections $(\sim-7 \%$ ) although carbonate particles are not composed of wellpreserved coccoliths raising questions on the reliability of these measurements. The record of the CIE 1 predates the emplacement of full anoxia and consecutive black shale deposition, as it is the case elsewhere in the south of the Paris Basin. With continuing sea level rise, reinvasion of coccoliths enabled sedimentation of carbonate and phytoplanktonic organic matter. Substantial high primary productivity led to anoxia, as observed at the scale of the entire NW European realm, and perhaps, more widely regarding the positive trend in carbon isotope as they are driven by a global phenomenon. Surprisingly, in the serpentinum zone a second prominent and stepped carbon isotope excursion (CIE 2) is registered, with a magnitude of $-6 \%$. Higher $\delta^{18} \mathrm{O}$ during each of the 


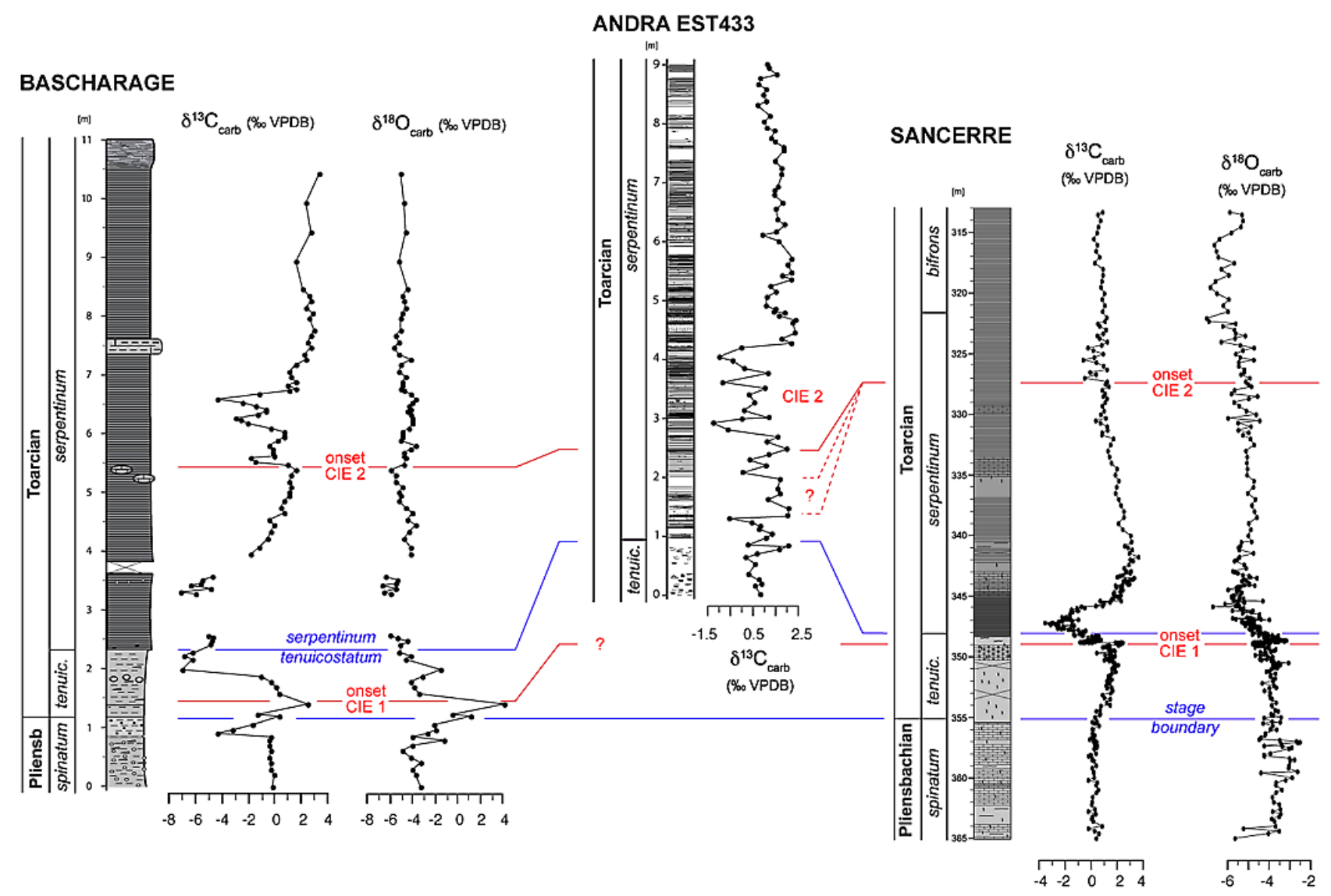

Figure 7. Attempt of a biostratigraphic and chemostratigraphic correlation of three well-documented Lower Toarcian sections of the Paris Basin. Blue lines indicate tentative biostratigraphic correlations. Red lines represent tentative chemostratigraphic correlations based on carbon isotope curves, and pinpoint the onsets of negative carbon isotope excursions. Two distinct CIEs are apparent: the first one (CIE 1) in the tenuicostatum zone (hence, correlated to the "worldwide" T-CIE), and the subsequent one (CIE 2) in the serpentinum zone. Data source: Bascharage (present study), EST433 (Lézin et al., 2013), Sancerre (Hermoso and Pellenard, 2014). The palaeogeographic location of each site is shown in Fig. 1a. Note that Sancerre corresponds to a much more expanded section compared to Bascharage and Sancerre.

carbon isotope negative steps provide evidence for a local control. We interpret this response in the "local" carbon cycle and in decreased temperatures of surface water mass by advection of bottom water masses. Future work, as generation of $\delta^{13} \mathrm{C}_{\text {org }}, \delta^{15} \mathrm{~N}_{\text {org }}$ or $\mathrm{TEX}_{86}$-based temperature estimates may help constraining palaeoenvironmental changes in such nearshore realm, together with a palaeoecological characterisation of nannofossil assemblages.

\section{The Supplement related to this article is available online at doi:10.5194/se-5-793-2014-supplement.}

Acknowledgements. The authors are indebted to Simone GuérinFraniatte (formerly at the University of Lorraine, France) for determination of ammonite specimens. We are also grateful to Norman Charnley, Jean-Marc Hénot, Nathalie Labourdette and Florence Savignac for help in the laboratory and sample processing. Our paper benefited from in-depth reviews by Chris Pearce and an anonymous referee. M. Hermoso was supported by a Ph.D. studentship by the Ministère de la Culture, de l'Enseignement Supérieur et de la Recherche of the Grand Duchy of Luxembourg (BFR 02/058) and subsequently by a Marie Curie-COFUND postdoctoral fellowship (AFR-PDR-002).

Edited by: A. Galy 


\section{References}

Bailey, T. R., Rosenthal, Y., McArthur, J. M., Van De Schootbrugge, B., and Thirlwall, M. F.: Paleoceanographic changes of the Late Pliensbachian-Early Toarcian interval: a possible link to the genesis of an Oceanic Anoxic Event, Earth Planet. Sc. Lett., 212, 307-320, 2003.

Bassoulet, J. P., Elmi, S., Poisson, A., Cecca, F., Bellion, Y., Guiraud, R., and Baudin, F.: Middle Toarcian (184-182 Ma), in: Atlas Tethys paleoenvironmental maps, edited by: Dercourt, J., Ricou L. E., and Vrielynck, B., Gauthier-Villards, Paris, 1993.

Baudin, F., Herbin, J. P., Bassoullet, J. P., Dercourt, J., Lachkar, G., Manivit, H., and Renard, M.: Distribution of organic matter during the Toarcian in the Mediterranean Tethys and Middle East, in: Deposition of organic facies, edited by: Huc, A. Y., AAPG studies in geology, 30, 73-91, 1990.

Boulvain, F., Belanger, I., Delsate, D., Dosquet, D., Ghysel, P., Godefroit, P., Laloux, M., Roche, M., Teerlynck, H., and Thorez, J.: New lithostratigraphical, sedimentological, mineralogical and palaeontological data on the Mesozoic of Belgian Lorraine: a progress report, Geol. Belgica, 3, 3-33, 2001.

Brański, P.: The mineralogical record of the Early Toarcian stepwise climate changes and other environmental variations (Ciechocinek Formation, Polish Basin), Volumina Jurassica, 10, 1-24, 2012.

Caruthers, A. H., Gröcke, D. R., and Smith, P. L.: The significance of an Early Jurassic (Toarcian) carbon-isotope excursion in Haida Gwaii (Queen Charlotte Islands), British Columbia, Canada, Earth Planet. Sc. Lett., 307, 19-26, 2011.

Delsate, D.: Deux nouveaux horizons à vertébrés (ChondrichthyesElasmobranchii et Osteichthyes-Actinopterygii) dans le Toarcien belge et limitrophe (Lorraine): synthèse stratigraphique et profils nouveaux, Belg. Geol. Survey Prof. Paper, 242, 53 pp., 1990.

Delsate, D. and Godefroit, P.: Chondrichthyens du Toarcien inférieur d'Aubange (Lorraine belge), Belg. Geol. Survey Prof. Paper, 278, 23-44, 1995.

Delsate, D., Godefroit, P., Stomp, N., Faber, A., Massard, J., Maubeuge, P. L., Boulvain, F., and Roche, M.: Remarques sur l'article de Henrotay, Marques, Paicheler, Gall and Nell (1998): "Le Toarcien inférieur des régions de Bascharage et de Bettembourg (Grand-Duché du Luxembourg): évidences paléontologiques et sédimentologiques d'environnements restreints proches de l'émersion", Bull. Acad. Soc. Lorr. Sci., 38, 15-27, 1999.

Dera, G., Pucéat, E. Pellenard, P., Neige, P., Delsate, D., Joachimski, M. M., Reisberg, L., and Martinez, M.: Water mass exchange and variations in seawater temperature in the NW Tethys during the Early Jurassic: Evidence from neodymium and oxygen isotopes of fish teeth and belemnites, Earth Planet. Sc. Lett., 286, 198207, 2009.

Elmi, S., Gabilly, J., Mouterde, R., Rulleau, L., and Da Rocha, R. B.: L'étage Toarcien de l'Europe et de la Téthys; Divisions et correlations, Geobios, 27, 149-159, 1994.

Elmi, S., Rulleau, L., Gabilly, J., and Mouterde, R.: 4. Toarcien, in: Biostratigraphie du Jurassique ouest-européen et méditerranéen: zonations parallèles et distribution des invertébrés et microfossiles, edited by: Cariou, E. and Hantzpergue, P., Bull. Cent. rech. explor. prod. Elf-Aquitaine, 17, 25-36, 1997.

Erba, E.: Calcareous nannofossils and Mesozoic oceanic anoxic events, Mar. Micropaleontol., 52, 85-106, 2004.
Espitalié, J., Deroo, G., and Marquis, F.: La pyrolyse Rock-Eval et ses applications, Première partie, Rev. Inst. Fr. Pét., 41, 76-89, 1986.

French, K. L., Sepúlveda, J., Trabucho-Alexandre, J., Gröcke, D. R., and Summons, R. E.: Organic geochemistry of the early Toarcian oceanic anoxic event in Hawsker Bottoms, Yorkshire, England, Earth Planet. Sc. Lett., 390, 116-127, 2014.

Gély, J. and Lorenz, J.: Syn-sedimentary tectonic and palaeogeographic reconstructions for each ammonite biozonation level, Geobios, 39, 631-649, 2006.

Gröcke, D. R., Hori, R. S., Trabucho-Alexandre, J., Kemp, D. B., and Schwark, L.: An open ocean record of the Toarcian oceanic anoxic event, Solid Earth, 2, 245-257, doi:10.5194/se-2-2452011, 2011.

Hanzo, M.: Milieu de dépôt et évolution diagénétique des argilites toarciennes d'après l'étude de nodules carbonatés des "Schistes carton" de Bettembourg (Grand-Duché de Luxembourg), Mém. Sci. Terre Nancy, 23, 45-59, 1979.

Hanzo, M. and Espitalié, J.: Relation entre matière organique et sédimentation dans le Lias de Lorraine (France), C. R. Acad. Sci., 316, 945-950, 1993.

Hardenbol, J., Thierry, J., Farley, M. B., Jacquin, T., De Graciansky, P. C., and Vail, P. R.: Mesozoic and Cenozoic sequence chronostratigraphic Framework of European basins, in: Mesozoic and Cenozoic Sequence Stratigraphy Of European Basins, edited by: De Graciansky, C., Hardenbol, J., Jacquin, T., and Vail, P. R., SEPM Special Publications, 60, Chart 4, 1998.

Henrotay, M., Marques, D., Paicheler, J.-C., Gall, J.-C., and Nel, A.: Le Toarcien inférieur des régions de Bascharage et de Bettembourg (grand-duché du Luxembourg: évidences paléontologiques et sédimentologiques d'environnements restreints proches de l'émersion, Geodiversitas, 20, 263-284, 1998.

Hermoso, M.: Les perturbations environnementales au cours du Toarcien inférieur. Apport de l'étude sédimentologique et géochimique de séries boréales et ouest-téthysiennes, Mém. Univ. P. et M. Curie, Paris, 326 pp., 2007.

Hermoso, M. and Pellenard, P.: Continental weathering and climatic changes inferred from clay mineralogy and paired carbon isotopes across the early to middle Toarcian in the Paris Basin, Palaeogeogr. Palaeocl., 399, 385-393, 2014.

Hermoso, M., Minoletti, F., Le Callonnec, L., Jenkyns, H. C., Hesselbo, S. P., Rickaby, R. E. M., Renard, M., de Rafélis, M., and Emmanuel, L.: Global and local forcing of Early Toarcian seawater chemistry: A comparative study of different paleoceanographic settings (Paris and Lusitanian basins), Paleoceanography, 24, 1-15, doi:10.1029/2009PA001764, 2009.

Hermoso, M., Minoletti, F., Rickaby, R. E. M., Hesselbo, S. P., Baudin, F., and Jenkyns, H. C.: Dynamics of a stepped carbonisotope excursion: Ultra high-resolution study of Early Toarcian environmental change, Earth Planet. Sc. Lett., 319, 45-54, 2012.

Hermoso, M., Minoletti, F., and Pellenard, P.: Black shale deposition during Toarcian super-greenhouse driven by sea level, Clim. Past, 9, 2703-2712, doi:10.5194/cp-9-2703-2013, 2013.

Hesselbo, S., Gröcke, D., Jenkyns, H., Bjerrum, C., Farrimond, P., Morgans Bell, H. S., and Green, O.: Massive dissociation of gas hydrate during a Jurassic oceanic anoxic event, Nature, 406, 392 395, 2000.

Hesselbo, S. P. and Pieńkowski, G.: Stepwise atmospheric carbonisotope excursion during the Toarcian Oceanic Anoxic Event 
(Early Jurassic, Polish Basin), Earth Planet. Sc. Lett., 301, 365372, 2011.

Irwin, H., Curtis, C., and Coleman, M.: Isotopic evidence for source of diagenetic carbonates formed during burial of organic-rich sediments, Nature, 269, 209-213, 1977.

Jenkyns, H. C.: The Early Toarcian (Jurassic) Anoxic Event, Am. J. Sci., 288, 101-151, 1988.

Jenkyns, H. C.: Evidence for rapid climate change in the MesozoicPalaeogene greenhouse, Phil. Trans. Royal Soc. (London) - Series A, 361, 1885-1916, 2003.

Jenkyns, H. C.: Geochemistry of oceanic anoxic events, Geochem. Geophy. Geosy., 11, 1-30, doi:10.1029/2009GC002788, 2010.

Jenkyns, H. C. and Clayton, C. J.: Black Shales and carbon isotopes in pelagic sediments from the Tethyan Lower Jurassic, Sedimentology, 33, 87-106, 1986.

Jenkyns, H. C. and Clayton, C. J.: Lower Jurassic epicontinental carbonates and mud- stones from England and Wales: chemostratigraphic signals and the early Toarcian anoxic event, Sedimentology, 44, 687-706, 1997.

Kemp, D., Coe, A., Cohen, A., and Schwark, L.: Astronomical pacing of methane release in the Early Jurassic period, Nature, 437, 396-399, 2005.

Küspert, W.: Environmental changes during oil shale deposition as deduced from stable isotope ratios, in: Cyclic and Event Stratification, edited by: Einsele, G. and Seilacher, A., Springer, Berlin, 482-501, 1982.

Lézin, C., Andreu, B., Pellenard, P., Bouchez, J.-L., Emmanuel, L., Fauré, P., and Landrein, P.: Geochemical disturbance and paleoenvironmental changes during the Early Toarcian in NW Europe, Chem. Geol., 341, 1-15, 2013.

Littler, K., Hesselbo, S. P., and Jenkyns, H. C.: A carbon-isotope perturbation at the Pliensbachian-Toarcian boundary: evidence from the Lias Group, NE England, Geol. Mag., 147, 181-192, 2010.

Lucius, M.: Das Gutland, Geologie Luxemburgs, Erläuterungen zu der geologische Spezialkarte Luxemburgs, Publ. Serv. Géol. Lux., 5, 405 pp., 1948.

Macchioni, F.: Myths and legends in the correlation between the Boreal and Tethyan Realms, Implications on the dating of the Early Toarcian mass extinctions and the Oceanic Anoxic Event, Geobios, 24, 150-163, 2002.

Marshall, J. D.: Climatic and oceanographic isotopic signals from the carbonate record and their preservation, Geol. Mag., 129, 143-160, 1992.

McElwain, J. C., Wade-Murphy, J., and Hesselbo, S. P.: Changes in carbon dioxide during an oceanic anoxic event linked to intrusion into Gondwana coals, Nature, 435, 479-482, 2005.

Minoletti, F., Hermoso, M., and Gressier, V.: Separation of sedimentary micron-sized particles for palaeoceanography and calcareous nannoplankton biogeochemistry, Nat. Protoc., 4, 14-24, 2009.

Morard, A., Guex, J., Bartolini, A., Morettini, E., and de Wever, P.: A new scenario for the Domerian - Toarcian transition, Bull. Soc. Géol. Fr., 174, 351-356, 2003.

Nel, A., Petrulevicius, J. F., and Henrotay, M.: New Early Jurassic sawflies from Luxembourg: the oldest record of Tenthredinoidea (Hymenoptera: "Symphyta"), Palaeont. Polonica Ac., 49, 283288, 2004.
Parisi, G., Ortega-Huertas, M., Nocchi, M., Palomo, I., Monaco, P., and Martinez, F.: Stratigraphy and geochemical anomalies of the Early Toarcian oxygen-poor interval in the Umbria-Marche Appennines (Italy), Geobios, 29, 469-484, 1996.

Röhl, H.-J., Schmid-Röhl, A., Oschmann, W., Frimmel, A., and Schwark, L.: The Posidonia Shale (Lower Toarcian) of SWGermany: an oxygen-depleted ecosystem controlled by sea level and palaeoclimate, Palaeogeogr. Palaeocl., 165, 27-52, 2001.

Rosales, I., Quesada, S., and Robles, S.: Primary and diagenetic isotopic signals in fossils and hemipelagic carbonates: the Lower Jurassic of northern Spain, Sedimentology, 48, 1149-1169, 2001.

Sabatino, N., Neri, R., Bellanca, A., Jenkyns, H. C., Baudin, F., Parisi, G., and Masetti, D.: Carbon-isotope records of the Early Jurassic (Toarcian) oceanic anoxic event from the Valdorbia (Umbria-Marche Apennines) and Monte Mangart (Julian Alps) sections: palaeoceanographic and stratigraphic implications, Sedimentology, 56, 1307-1328, 2009.

Sælen, G., Tyson, R. V., Telnæs, N., and Talbot, M. R.: Contrasting watermass conditions during deposition of the Whitby Mudstone (Lower Jurassic) and Kimmeridge Clay (Upper Jurassic) formations, UK, Palaeogeogr. Palaeocl., 163, 163-196, 2000.

Sandoval, J., Bill, M., Aguado, R., O’Dogherty, L., Rivas, P., Morard, A., and Guex, J.: The Toarcian in the Subbetic basin (southern Spain): Bio-events (ammonite and calcareous nannofossils) and carbon-isotope stratigraphy, Palaeogeogr. Palaeocl., 342, 40-63, 2012.

Service Géologique: Carte géologique du Grand-Duché de Luxembourg, Publ. Serv. Géol. Lux., svailable at: http://www.pch. public.lu/publications/cartes/publ_SGL_cartes_geol/, 1998.

Suan, G., Mattioli, E., Pittet, B., Mailliot, S., and Lécuyer, C.: Evidence for major environmental perturbation prior to and during the Toarcian (Early Jurassic) Oceanic Anoxic Event from the Lusitanian Basin, Portugal, Paleoceanography, 23, PA1202, doi:10.1029/2007PA001459, 2008.

Svensen, H., Planke, S., Chevallier, L., Malthe-Sørenssen, A., Corfu, F., and Jamtveit, B.: Hydrothermal venting of greenhouse gases triggering Early Jurassic global warming, Earth Planet. Sc. Lett., 256, 554-566, 2007.

Tissot, B., Califet-Debyser, Y., Deroo, G., and Oudin, J. L.: Origin and evolution of hydrocarbons in early Toarcian shales, Paris Basin, France, AAPG Bull., 55, 2177-2193, 1971.

Van Breugel, Y., Baas, M., Schouten, S., Mattioli, E., and Sinninghe Damsté, J. S.: Isorenieratane record in black shales from the Paris Basin, France: Constraints on recycling of respired $\mathrm{CO}_{2}$ as a mechanism for negative carbon isotope shifts during the Toarcian oceanic anoxic event, Paleoceanography, 21, PA4220, doi:10.1029/2006PA001305, 2006.

Van de Schootbrugge, B., McArthur, J. M., Bailey, T. R., Rosenthal, Y., Wright, J. D., and Miller, K. G.: Toarcian oceanic anoxic event: An assessment of global causes using belemnite C-isotope records, Paleoceanography, 20, PA3008, doi:10.1029/2004PA001102, 2005.

Woodfine, R. G., Jenkyns, H. C., Sarti, M., Baroncini, F., and Violante, C.: The response of two Tethyan carbonate platforms to the early Toarcian (Jurassic) oceanic anoxic event: environmental change and differential subsidence, Sedimentology, 55, 10111028, 2008. 